IZA DP No. 5513

The Right Look: Conservative Politicians

Look Better and Their Voters Reward It

Niclas Berggren

Henrik Jordahl

Panu Poutvaara

February 2011 


\title{
The Right Look: \\ Conservative Politicians Look Better and Their Voters Reward It
}

\author{
Niclas Berggren
}

Ratio Institute

Henrik Jordahl

Research Institute of Industrial Economics (IFN)

and IZA

Panu Poutvaara

University of Munich,

Ifo Institute and IZA

\section{Discussion Paper No. 5513}

February 2011

\section{IZA}

P.O. Box 7240

53072 Bonn

Germany

Phone: +49-228-3894-0

Fax: +49-228-3894-180

E-mail: iza@iza.org

Any opinions expressed here are those of the author(s) and not those of IZA. Research published in this series may include views on policy, but the institute itself takes no institutional policy positions.

The Institute for the Study of Labor (IZA) in Bonn is a local and virtual international research center and a place of communication between science, politics and business. IZA is an independent nonprofit organization supported by Deutsche Post Foundation. The center is associated with the University of Bonn and offers a stimulating research environment through its international network, workshops and conferences, data service, project support, research visits and doctoral program. IZA engages in (i) original and internationally competitive research in all fields of labor economics, (ii) development of policy concepts, and (iii) dissemination of research results and concepts to the interested public.

IZA Discussion Papers often represent preliminary work and are circulated to encourage discussion. Citation of such a paper should account for its provisional character. A revised version may be available directly from the author. 
IZA Discussion Paper No. 5513

February 2011

\section{ABSTRACT \\ The Right Look: \\ Conservative Politicians Look Better and Their Voters Reward It}

Previous research has established that good-looking political candidates win more votes. We extend this line of research by examining differences between parties on the left and on the right of the political spectrum. Our study combines data on personal votes in real elections with a web survey in which 2,513 non-Finnish respondents evaluated the facial appearance of 1,357 Finnish political candidates. We find that political candidates on the right are better looking in both municipal and parliamentary elections and that they have a larger beauty premium in municipal, but not in parliamentary, elections. As municipal candidates are relatively unknown, the beauty-premium gap indicates that voters - especially those to the right - use beauty as a cue for candidate ideology or quality in the municipal elections.

JEL Classification: $\quad$ D72, J45, J70

Keywords: beauty, elections, political candidates, appearance, ideology, parties

Corresponding author:

Panu Poutvaara

Ifo Institute for Economic Research

Poschingerstr. 5

81679 Munich

Germany

E-mail: poutvaara@ifo.de

\footnotetext{
* The authors contributed equally to the paper. We wish to thank Massimo Bordignon, Mikael Elinder, Silke Friedrich, Veronica Grembi, Friedrich Heinemann, Juha Itkonen, Erik Lindqvist, Heléne Lundqvist, Pierre-Guillaume Méon, Mattias Nordin, Torsten Persson, Andreas Wagener, conference participants at the 2010 Meeting of the European Public Choice Society, the 2010 CESifo Public Sector Area Conference, the 2010 IIPF annual congress, the 2010 National Conference of Swedish Economists, and seminar participants at Uppsala University and Université Libre de Bruxelles for helpful comments and suggestions, all respondents and those who helped us attract them (especially our colleagues, who advertised the study to their students in several countries, and several bloggers), Otto Kässi for excellent research assistance, Karl Hammar for outstanding technical assistance, and the Jan Wallander and Tom Hedelius Foundation (Jordahl) and the Yrjö Jahnsson Foundation (Poutvaara) for financial support.
} 


\section{Introduction}

The facial appearance of political candidates and their electoral success are related: better-looking candidates win more votes (Todorov et al., 2005; Ballew and Todorov, 2007; Antonakis and Dalgas, 2009; Benjamin and Shapiro, 2009; Poutvaara et al., 2009; King and Leigh, 2009; Berggren et al., 2010; Rule at al., 2010; Lawson et al., 2010; Olivola and Todorov, 2010). While this has been established as a general relationship, none of the studies look at differences in beauty or in beauty premia between political candidates from the left and from the right. A beauty gap between the main parties could give candidates from one side an edge in elections, suggesting a possible link from candidate appearance to policy outcomes. A related question is whether voters on the left and on the right are equally sensitive to the looks of candidates. If not, the parties whose voters are more responsive to appearance might be expected to select and attract better-looking candidates. Since voters who are less responsive to candidate appearance could be more responsive to policy, a vote maximizing party might be expected to gear its policy platform towards this group of voters, e.g., by targeted redistribution. ${ }^{1}$

We make use of a rich dataset of Finnish political candidates from different parties. The candidates were evaluated, through a web survey, by a large number of respondents from other countries on traits such as beauty and competence, and we relate those evaluations to the votes each candidate received in parliamentary and municipal elections. Given that Todorov et al. (2005), Ballew and Todorov (2007) and Antonakis and Dalgas (2009) have found that inferences of competence predict electoral success, we include photograph-based competence evaluations in our investigation, both separately and together with

\footnotetext{
${ }^{1}$ On the importance of physical appearance for how people are perceived and treated outside of politics, see, e.g., Hamermesh and Biddle (1994), Langlois et al. (2000), Rule and Ambady (2008) and Todorov et al. (2011). On the evolutionary origins of an appreciation of beauty, see the original contribution by Darwin (1871) and recent evidence in Grammer et al. (2003). On the correlation between beauty and intelligence, see Kanazawa (2011). There are also some experimental studies that link facial appearance to participants' own behavior and treatment of others: see Mulford et al. (1998), Solnick and Schweitzer (1999), Mobius and Rosenblat (2006), Wilson and Eckel (2006), and Andreoni and Petrie (2008).
} 
beauty.

We focus our analysis on the National Coalition Party on the right and on the Social Democratic Party and the Left Alliance on the left. In Finland, as in most democracies, there is a clear left-right pattern in politics, with one or several parties on each side. ${ }^{2}$ Finland's proportional electoral system with personal votes enables us to estimate electoral beauty premia from within-party competition. This allows us to isolate the effect of beauty from other vote motives, like ideology, and to handle other empirical problems related to the selection and quality of candidates.

In the 2003 Finnish National Election Study, most voters reported having been influenced by the political opinions and the party of the candidates when making their choice. But several other factors were also influential, including the experience, education, gender, fame and age of the candidates. Notably, more than one third of the voters were influenced by the presence and style of the candidates and more than one fifth by their election campaigns and advertisements. Table A.1 in the Appendix presents these numbers separately for right and left voters. For our purposes, it is eye-catching that voters who are politically to the right state that they were more influenced by education, presence and style, as well as by campaigns and advertisements, whereas voters to the left say that they were more influenced by the gender of the candidates.

We establish two main results. First, we find that candidates on the right look better than candidates on the left. Second, we find a greater effect of good looks, in terms of more votes, for candidates on the right. The difference in appearance is found both in parliamentary and in municipal elections, whereas the difference in the electoral effects of appearance is only found in municipal elections. Based on the fact that municipal candidates are relatively unknown, we discuss possible explanations for this pattern.

\footnotetext{
${ }^{2}$ Budge and Robertson (1987: 394-395) differentiate between left and right in terms of "economic-policy conflicts - government regulation of the economy through direct controls or takeover ... as opposed to free enterprise, individual freedom, incentives and economic orthodoxy." On the usage and relevance of this terminology in modern politics, see Klingemann (1995), Bobbio (1996) and - for the Nordic countries - Grendstad (2003). Although politically relevant, left-right terminology involves simplification (Mair, 2007), and the exact meaning of the terms differ somewhat between political cultures (Zechmeister, 2006).
} 


\section{Method}

\subsection{Survey and Data}

The basis for this study is a web survey based on photographs of Finnish political candidates with respondents from outside of Finland to ensure that the candidates were not recognized. Our data collection method comprised recruitment of students by colleagues at lectures at several universities as well as recruitment via newspaper and magazine articles and blogs. Each respondent was shown four photographs (two of each gender), one at a time, randomly chosen from the database of photographs, and was asked to evaluate each photograph, e.g., in terms of attractiveness and competence. ${ }^{3}$ There was no time limit for looking at the photographs. To exemplify, one question was:

What is your evaluation of the physical appearance or attractiveness of this person compared to the average among people living in your country of residence?

Very unattractive (1)

Below average (2)

Average (3)

Above average (4)

Very handsome or beautiful (5)

Cannot say/Prefer not to answer

For our data analysis, the replies were coded from 1 to 5 , as indicated above, but the numbers did not appear in the survey. ${ }^{4}$ In this paper we study candidates from one party to the right, the National

\footnotetext{
${ }^{3}$ Respondents could choose to evaluate further rounds of four photos and also, if so, choose to only look at photos of candidates of one particular gender.

${ }^{4}$ All of the results in the paper are qualitatively unaffected (but rescaled) if we use the share of respondents who replied that a political candidate was "Above average" or "Very handsome or beautiful" rather than relying on the 1-5 scale as our measure of beauty (and of competence).
} 
Coalition Party, and from two parties to the left, the Social Democratic Party and the Left Alliance.

\subsection{Photographs}

From a database containing 1,929 photographs of Finnish political candidates, we study photographs of candidates from the parties that can be classified to the political right or to the political left: the National Coalition Party, the Social Democratic Party and the Left Alliance. We only include evaluations by respondents who evaluated at least four photographs, and only photographs with at least three evaluations. This gives us 1,357 photographs in total, with an average of nine respondents per photograph. The photographs can be divided into 684 of women and 673 of men; 575 from the 2003 parliamentary election and 782 from the 2004 municipal elections; and 1,170 of non-incumbents and 187 of incumbents. ${ }^{5}$ The photos only showed the faces of the candidates. No information was given about any candidate. Respondents were asked to report if they recognized any of the candidates. None of the respondents recognized a single candidate by name.

The photographs used were displayed by the political parties on their campaign posters as well as in newspaper ads. Most voters can be expected to have seen most candidate photographs. There are two potential problems related to the use of candidate photographs. The first one is reverse causality - it could be that successful politicians have access to better photographers and stylists. The second one is omitted variables, if some politicians both dress in a certain way and do other unobserved things, like visit large numbers of voters, which help them getting elected. However, we expect both problems to be smaller when using official candidate photos. One problem we avoid is that more successful or better financed candidates hire better photographers. Likewise, a "bad hair day" would produce measurement error for a candidate if photos from the press were used, whereas with official candidate photos, one expects an

\footnotetext{
${ }^{5}$ By incumbent is meant a political candidate who served in the office in question, or as members of the national or the European parliaments, at the time of the election.
} 
unflattering picture exposed in numerous posters to be detrimental for electoral success. In any case, Hamermesh et al. (2002) find that clothes and makeup only affect perceptions of a person's beauty marginally. Finally, there are no indications that some parties spend more or less on having photographs taken of their candidates, or that the quality of the candidate photos differs between parties.

\subsection{Respondents}

We had 2,513 respondents. This number greatly exceeds the number of respondents in comparable studies on the role of facial appearance in politics. In the pioneering study by Todorov et al. (2005), only 34 out of 843 respondents evaluated beauty. King and Leigh (2009) used 5 respondents. The majority of our respondents were from Sweden or the United States, but we also had significant participation from France, Germany and Denmark. As reported in Berggren et al. (2010), we find that respondents in different Western countries make similar evaluations. Lawson et al. (2010) generalize this finding to more dissimilar countries by demonstrating that evaluations by subjects living in the United States and India predict actual election outcomes in Mexico and Brazil quite accurately. Likewise, Rule et al. (2010) report that American and Japanese participants made similar inferences of traits from the faces of both U.S. and Japanese political candidates, and their evaluations predicted election outcomes between cultures.

\subsection{Electoral System}

Finland has a proportional electoral system in both municipal and parliamentary elections. Each voter has to vote for one candidate on a party list. Unlike in some other countries, it is not possible to vote for a list without picking a candidate. The seats are allocated to different parties based on their vote shares, using the d'Hondt seat-allocation rule. Candidates from a given party are elected in the order of their personal votes in their district. Elections are held every four years.

Each municipality forms one district in municipal elections. The number of elected municipal 
councilors depends on the population of the municipality, reaching a maximum of 85 in Helsinki. Each party is allowed to present one and a half as many candidates on its list as the number of seats in the municipal council.

At the national level, Finland has a one-chamber legislature with 200 members. The country is divided into 14 electoral districts that elect 199 MPs and an autonomous region (Åland) electing one MP. We study the 14 mainland districts. The number of candidates that a party can present equals the number of representatives elected from the district, if this is 14 or more. In small districts with less than 14 seats, a party can present 14 candidates.

In the 2003 parliamentary election, turnout was $70 \%$. Female candidates received $43 \%$ of all votes and won 75 of the 200 seats in parliament (Nurmi and Nurmi, 2004). ${ }^{6}$ In the 2004 municipal elections, turnout was $59 \%$.

\subsection{Voter Information about Municipal and Parliamentary Candidates}

Electoral competition works quite differently at the municipal and at the national level. To win a seat in parliament, a candidate normally has to first win a seat in the municipal council. ${ }^{7}$ Politics is more competitive at the national level.

Municipal elections can be characterized as low-information elections - defined by Buckley et al. $(2007,176)$ as "elections which do not involve significant constitutional office and do not attract large scale media coverage" - as only a few candidates (especially among non-incumbents) are "career politicians" who are politicians by occupation or have a history of active campaigning and public visibility. Advertising is mainly restricted to posters and newspaper ads; hardly any candidates run individual campaigns in television or radio.

\footnotetext{
${ }^{6}$ Raunio (2005) presents more facts about the Finnish political system.

${ }^{7}$ Likewise in the next stage, a candidate who wants to win a seat in the European Parliament normally has to win a seat in the national parliament first.
} 
In contrast, the parliamentary election can be characterized as one of high information. Many parliamentary candidates have previously held seats at the municipal level and have a political history that voters are aware of. Candidates who spend large amounts of money on campaigning are mainly observed in the parliamentary election. Parliamentary candidates are a more select group that is, for several reasons, more visible to the public.

Table A.2 in the Appendix lists the share of different occupations for the candidates in our sample, as reported on electoral lists, in the municipal and in the parliamentary elections. The striking difference between the elections is that one of eight parliamentary candidates but only one of 42 municipal candidates was working as a "political leader". In most cases this means serving as MP. At the municipal level, only $15 \%$ of the incumbents are working as "political leaders" (including as MPs).

\section{Beauty and Electoral Success in Low-Information Elections}

In this Section we compare evaluations of left and right municipal candidates and investigate how the evaluations are related to electoral success in municipal elections. As the total amount of easily available information about the candidates is much smaller in municipal than in parliamentary elections, the looks of candidates could be relatively more important to voters in the former elections. We present corresponding results for parliamentary candidates in Section 4. 


\subsection{Trait Evaluations}

We begin by reporting the average trait evaluations of the municipal candidates. Table 1 reveals that right candidates are seen as more good-looking than left candidates, and are to a lesser extent also seen as more competent. Female candidates (both right and left) receive higher beauty evaluations than male candidates, whereas competence evaluations are more equal for females and males. Incumbents are generally evaluated as better looking and more competent than non-incumbents. ${ }^{8}$ The correlation coefficient between beauty and competence is $0.39 .{ }^{9}$

Before moving on to the electoral effects of good looks we have to address a potential problem relating to the validity of the trait evaluations. Since it is likely that right and left candidates chose to present themselves in a somewhat different fashion (e.g., with regard to haircut, clothing, glasses, jewelry), there is a risk that the evaluations reflect the political orientation of the respondents. In particular, our use of foreign respondents could be problematic if, for instance, U.S. respondents are more conservative on average and therefore evaluate right political candidates as relatively better looking. We address this issue from three angles. First, we divide the respondents according to their view on taxes and redistribution to investigate if the evaluation differences are driven by the political orientation of the respondents. Second, we compare the evaluations of respondents from Sweden and respondents from the United States. Third, we test if political candidates who wear a tie (for men) or a blouse and/or a suit (for women) are given different evaluations than those who do not.

\footnotetext{
${ }^{8}$ The trait differences in Table 1 cannot be explained by age differences between left and right candidates. The mean age of left and right candidates differ by less than one year. Male candidates are four years older than female candidates and incumbents are seven years older than non-incumbents, on average.

${ }^{9}$ The correlation coefficient is 0.40 among male and 0.42 among female candidates, and 0.38 among right and 0.37 among left candidates.
} 
TABLE 1. Average trait evaluations, municipal elections (standard deviations in parentheses).

\begin{tabular}{|c|c|c|c|}
\hline & Beauty & Competence & Number of candidates \\
\hline Right candidates & $2.89(0.71)$ & $3.32(0.41)$ & 263 \\
\hline $\mathrm{p}$-value of difference & 0.000 & 0.001 & \\
\hline Left candidates & $2.59(0.61)$ & $3.20(0.45)$ & 518 \\
\hline Right female candidates & $3.08(0.79)$ & $3.34(0.37)$ & 140 \\
\hline p-value of difference & 0.000 & 0.000 & \\
\hline Left female candidates & $2.63(0.67)$ & $3.17(0.41)$ & 240 \\
\hline Right male candidates & $2.68(0.53)$ & $3.30(0.45)$ & 123 \\
\hline p-value of difference & 0.045 & 0.247 & \\
\hline Left male candidates & $2.56(0.60)$ & $3.24(0.49)$ & 278 \\
\hline Right female incumbents & $3.05(0.76)$ & $3.34(0.34)$ & 22 \\
\hline $\mathrm{p}$-value of difference & 0.190 & 0.831 & \\
\hline Left female incumbents & $2.78(0.63)$ & $3.36(0.47)$ & 26 \\
\hline Right male incumbents & $2.77(0.51)$ & $3.48(0.28)$ & 25 \\
\hline $\mathrm{p}$-value of difference & 0.055 & 0.640 & \\
\hline Left male incumbents & $2.50(0.52)$ & $3.43(0.48)$ & 24 \\
\hline Right female non-incumbents & $3.08(0.80)$ & $3.34(0.38)$ & 118 \\
\hline $\mathrm{p}$-value of difference & 0.000 & 0.000 & \\
\hline Left female non-incumbents & $2.61(0.67)$ & $3.14(0.39)$ & 214 \\
\hline Right male non-incumbents & $2.65(0.54)$ & $3.26(0.47)$ & 98 \\
\hline p-value of difference & 0.184 & 0.582 & \\
\hline Left male non-incumbents & $2.56(0.55)$ & $3.23(0.78)$ & 254 \\
\hline All municipal candidates & $2.69(0.66)$ & $3.25(0.44)$ & 781 \\
\hline
\end{tabular}

Notes: Right candidates belong to the National Coalition Party. Left candidates belong to the Social Democratic Party or to the

Left Alliance. An incumbent is a political candidate who served in the office in question, or as a member of the national or the European parliaments, at the time of the election. One observation is the average evaluation of one candidate. P-values from a t-test of equal means are reported between each pair of average evaluations of right and left candidates.

As reported in Table A.3 in the Appendix, the beauty differences between right and left candidates remain both for right and for left respondents (as classified by whether they agree or disagree with the suggestion "to increase taxes on those with high incomes in your country, and distribute the money to those with low incomes."). For male candidates the beauty difference is, however, not statistically significant when evaluated by left respondents. The differences in competence also remain in Table A.3, but are smaller and in some cases statistically insignificant. Table A.4 in the Appendix reveals that right candidates are perceived as more beautiful and competent both by respondents from Sweden and from the United Sates (although for male candidates the differences are not statistically significant among respondents from Sweden). Table A.5 demonstrates that what candidates wear only seems to affect how competent they are perceived to be. For beauty the difference is statistically insignificant throughout the Table. We also note that it does not seem to be the case that respondents to the right react differently to 
male candidates wearing a tie or female candidates wearing a blouse and/or a suit than respondents to the left do. We conclude that the higher beauty and competence evaluations of right candidates do not just reflect the political opinions of the respondents. While the competence evaluations are, to some extent, related to what the candidates wear, the relationship does not differ between respondents to the left and to the right.

\subsection{Electoral Success}

We now turn to regression analysis to investigate the relationship between the trait evaluations and electoral success. We focus on non-incumbent candidates, as Berggren et al. (2010) showed that appearance does not matter as much for incumbents..$^{10}$ Appearance and other pieces of information may be more important for less well-known candidates, and an incumbency dummy may not fully capture such differences. ${ }^{11}$ We make use of list fixed effects in our regressions, to capture how beautiful and competent a candidate is perceived to be in relation to the other candidates on the same list. We compare the electoral success of candidates from the National Coalition Party on the right, and from the Social Democratic Party and the Left Alliance on the left. ${ }^{12}$

Our dependent variable, Relative success, is defined in the following way for candidate $i$ on list $j$ :

$$
\text { Relative } \operatorname{success}_{i, j}=\left(p_{i} / v_{j}\right) * 100
$$

\footnotetext{
${ }^{10}$ We are able to study non-incumbents separately as Finland has a proportional electoral system with personal votes determining the order in which candidates are elected, resulting in within-party competition. A plurality-vote system, like that of the United States, typically features competition between an incumbent and a challenger from another party.

${ }^{11}$ Caughey and Sekhon (2010) demonstrate the difficulty of estimating the incumbency advantage.

${ }^{12}$ The pooling of candidates from the Social Democratic Party and the Left Alliance is supported by statistical tests; there is no specification in which we can reject (at the $5 \%$ significance level) that the beauty coefficients are equal for candidates from these two parties.
} 
where $p_{i}$ is candidate $i$ 's number of personal votes and $v_{j}$ is the number of all votes for candidates on list $j$ divided by the number of candidates on list $j$. As explanatory variables, we use the two trait variables Beauty and Competence. The trait variables are standardized: each mean assessment is divided by the standard deviation of all the mean assessments of that trait so that the trait variables all have a standard deviation of one. The beauty and competence variables are interacted with a dummy variable for right candidates (i.e., candidates who belong to the National Coalition Party). We also include a dummy variable for male candidates, both by itself and interacted with Right. ${ }^{13}$ Table 2 contains the regression results that allow us to compare the beauty and competence coefficients of right and left candidates. Since our identification comes from the interaction of the two trait variables Beauty and Competence with the dummy variable Right, we include the interaction of all unreported dummy variables with Right in most specifications, but we do not report estimates for the full set of interaction terms in the Table. The unreported dummies are Young, which denotes an age under 30, and Old, which denotes an age over 60, together with dummies for education and occupation.

\footnotetext{
${ }^{13}$ No definitive gender differences with regard to beauty premia could be established by Berggren et al. (2010); however, other studies indicate that gender sometimes does matter for reactions to beauty. For example, Dreber et al. (2010) find that male chess players choose significantly riskier strategies when playing against an attractive female opponent, although this does not improve their performance.
} 
TABLE 2. Relative success in the municipal elections, non-incumbents.

\begin{tabular}{|c|c|c|c|c|c|c|c|c|c|}
\hline & (1) & (2) & (3) & (4) & $(5)$ & (6) & (7) & $(8)$ & (9) \\
\hline Beauty & $\begin{array}{c}15.40^{* * *} \\
(4.33)\end{array}$ & $\begin{array}{l}15.91 * * * \\
(4.62)\end{array}$ & $\begin{array}{c}14.95^{* * *} \\
(5.15)\end{array}$ & & & & $\begin{array}{l}8.62^{* * *} \\
(3.49)\end{array}$ & $\begin{array}{l}8.32 * \\
(3.62)\end{array}$ & $\begin{array}{c}8.49 \\
(5.27)\end{array}$ \\
\hline Beauty $\times$ Right & $\begin{array}{l}15.59^{*} \\
(7.94)\end{array}$ & $\begin{array}{c}18.64 * * \\
(5.67)\end{array}$ & $\begin{array}{c}15.24 * * \\
(6.20)\end{array}$ & & & & $\begin{array}{c}22.60 * * \\
(7.67)\end{array}$ & $\begin{array}{c}27.86^{* * * *} \\
(4.85)\end{array}$ & $\begin{array}{c}25.35 * * * \\
(6.34))\end{array}$ \\
\hline Competence & & & & $\begin{array}{l}18.94 * * * \\
(5.28)\end{array}$ & $\begin{array}{l}18.77 * * * \\
(5.41)\end{array}$ & $\begin{array}{c}16.70 * * \\
(5.85)\end{array}$ & $\begin{array}{c}14.75 * * \\
(5.16)\end{array}$ & $\begin{array}{c}15.28 * * \\
(5.09)\end{array}$ & $\begin{array}{l}12.99 * \\
(6.29)\end{array}$ \\
\hline Competence $\times$ Right & & & & $\begin{array}{l}-9.05 \\
(9.17)\end{array}$ & $\begin{array}{l}-8.56 \\
(9.38)\end{array}$ & $\begin{array}{l}-14.84 \\
(8.06)\end{array}$ & $\begin{array}{c}-18.87 * * \\
(8.04)\end{array}$ & $\begin{array}{c}-20.18^{* *} \\
(8.32)\end{array}$ & $\begin{array}{c}-24.36^{* *} \\
(8.12)\end{array}$ \\
\hline Male dummy & $\begin{array}{l}-20.66 \\
(16.32)\end{array}$ & $\begin{array}{l}-33.84 \\
(19.31)\end{array}$ & $\begin{array}{c}-34.41 * \\
(15.51)\end{array}$ & $\begin{array}{l}-28.25^{*} \\
(14.87)\end{array}$ & $\begin{array}{l}-36.15^{*} \\
(18.27)\end{array}$ & $\begin{array}{c}-36.43 * * \\
(14.69)\end{array}$ & $\begin{array}{l}-22.42 \\
(16.01)\end{array}$ & $\begin{array}{c}-35.85^{*} \\
(18.56)\end{array}$ & $\begin{array}{c}-36.09 * * \\
(14.93)\end{array}$ \\
\hline Male dummy $\times$ Right & & $\begin{array}{l}42.79 \\
(24.86)\end{array}$ & $\begin{array}{l}32.66 \\
(23.23)\end{array}$ & & $\begin{array}{c}22.84 \\
(28.47)\end{array}$ & $\begin{array}{l}11.08 \\
(28.38)\end{array}$ & & $\begin{array}{l}45.08 \\
(24.44)\end{array}$ & $\begin{array}{c}34.89 \\
(23.52)\end{array}$ \\
\hline Age dummies & Yes & Yes & Yes & Yes & Yes & Yes & Yes & Yes & Yes \\
\hline $\begin{array}{l}\text { Education and } \\
\text { occupation dummies }\end{array}$ & No & No & Yes & No & No & Yes & No & No & Yes \\
\hline $\begin{array}{l}\text { Unreported dummies } \\
\text { interacted with Right }\end{array}$ & No & Yes & Yes & No & Yes & Yes & No & Yes & Yes \\
\hline List fixed effects & Yes & Yes & Yes & Yes & Yes & Yes & Yes & Yes & Yes \\
\hline Number of candidates & 682 & 682 & 682 & 682 & 682 & 682 & 682 & 682 & 682 \\
\hline R-squared & 0.02 & 0.02 & 0.05 & 0.02 & 0.03 & 0.06 & 0.06 & 0.08 & 0.14 \\
\hline
\end{tabular}

Notes: The dependent variable is Relative success. Right candidates belong to the National Coalition Party. Left candidates belong to the Social Democratic Party or to the Left Alliance. The education dummies are Comprehensive school or less (at most 10 years of schooling); Upper-secondary education (corresponds to 12 years of schooling); Vocational education (10-12 years of schooling); and University education (those who have completed their education and obtained degrees). Upper-secondary education usually serves as preparation for university-level education, and many of the candidates with upper-secondary education listed as highest education have started, but not completed, university studies. Vocational education includes, e.g., basic nurses, nurses, commercial school graduates, clerks, and artisans. The occupational dummies are political leader, party worker, management, researcher, teacher, upper white collar, medical doctor, nurse, lower white collar, worker, entrepreneur, artist, student, and not employed. Robust standard errors clustered at the list level in parentheses. * significant at $10 \%$; ** significant at $5 \%$;** significant at $1 \%$.

Table 2 contains nine specifications that vary in three dimensions: whether we include Beauty and/or Competence, whether we control for education and occupation, and whether we interact the variables with unreported coefficients (age, education and occupation) with Right. The Table shows that in the municipal elections, the beauty coefficient of right candidates is between two and four times as large as that of left candidates (the total beauty coefficient of right candidates is obtained by adding the coefficients for Beauty and Beauty $\times$ Right). The difference between the competence coefficients of right and left candidates is generally smaller, although perceived competence only seems to matter for left 
candidates.

Neither the beauty nor the competence coefficients are much affected by including dummies for education and occupation. However, both the beauty and the competence coefficients are somewhat sensitive to including the other trait in the regression. When we include beauty and competence simultaneously in columns $7-9$, the beauty coefficient falls for left and rises for right candidates (compared with columns 1-3). The competence coefficient is reduced (compared with columns 4-6), but only marginally so for left candidates. The competence coefficient of left and that of right candidates are however only statistically different from zero at the $10 \%$ significance level when including the education and occupation controls and interacting all variables with Right (in column 9).

Beauty and competence display different relationships with electoral success for right and left candidates. The large beauty estimates (primarily for right candidates) obtained when controlling for competence, education and occupation, as well as a full set of interaction terms (column 9), suggest that beauty is related to electoral success by itself and not just as a sign of competence. The relationship between competence and electoral success is estimated with less precision and the negative coefficients for right candidates imply a weaker relationship over the full sample of left and right candidates.

The estimates also suggest that female left candidates do better than male left candidates. For right candidates there is, however, no visible gender difference. In accordance with McDermott (1997), our interpretation is that voters use gender as a cue in low-information elections. Since women are typically seen as kinder and more compassionate than men, they are stereotyped as caring more about social welfare issues, which could make them preferable to men on a left party list with relatively unknown candidates.

Finally, Table A.6 in the Appendix reports results for specifications that include both incumbents and non-incumbents. We note that the incumbency coefficient generally exceeds that of beauty by an order of magnitude. The estimated coefficients suggest that there is a positive relationship between beauty and electoral success, but we cannot reject that the relationship is the same for right and left candidates. The competence coefficients are small and statistically insignificant, both for left and right candidates. 


\section{Beauty and Electoral Success in High-Information Elections}

In this Section, we turn to politics at the national level. Compared with municipal elections, voters have considerably more information about the candidates in parliamentary elections.

\subsection{Trait Evaluations}

Table 3 shows that right candidates are judged to be better looking than left candidates also in the parliamentary election. Right parliamentary candidates are also generally seen as more competent than left candidates. ${ }^{14}$ The correlation coefficient between beauty and competence is $0.36 .{ }^{15}$ Compared with the municipal candidates in Table 2, the parliamentary candidates look slightly better and more competent.

\footnotetext{
${ }^{14}$ The trait differences in Table 3 cannot be explained by age differences between left and right candidates. As in Table 1, the mean age of left and right candidates differ by less than one year.

${ }^{15}$ The correlation coefficient is 0.33 among male and 0.45 among female candidates, and 0.28 among right and 0.37 among left candidates.
} 
TABLE 3. Average trait evaluations, parliamentary elections (standard deviations in parentheses).

\begin{tabular}{lccc}
\hline & Beauty & Competence & Number of candidates \\
\hline Right candidates & $2.93(0.62)$ & $3.55(0.45)$ & 202 \\
p-value of difference & 0.000 & 0.000 & \\
Left candidates & $2.70(0.67)$ & $3.31(0.51)$ & 373 \\
\hline Right female candidates & $3.06(0.67)$ & $3.52(0.40)$ & 108 \\
p-value of difference & 0.000 & 0.000 & \\
Left female candidates & $2.82(0.74)$ & $3.29(0.46)$ & 195 \\
\hline Right male candidates & $2.78(0.51)$ & $3.58(0.49)$ & 94 \\
p-value of difference & 0.002 & 0.000 & \\
Left male candidates & $2.56(0.56)$ & $3.34(0.55)$ & 178 \\
\hline Right female incumbents & $3.54(0.52)$ & $3.87(0.36)$ & 16 \\
p-value of difference & 0.001 & 0.001 & 25 \\
Left female incumbents & $2.93(0.53)$ & $3.45(0.36)$ & 21 \\
\hline Right male incumbents & $2.92(0.57)$ & $3.64(0.44)$ & 28 \\
p-value of difference & 0.012 & 0.214 & 92 \\
Left male incumbents & $2.52(0.49)$ & $3.45(0.55)$ & \\
\hline Right female non-incumbents & $2.98(0.66)$ & $3.45(0.38)$ & 170 \\
p-value of difference & 0.070 & 0.001 & 73 \\
Left female non-incumbents & $2.81(0.76)$ & $3.27(0.76)$ & 150 \\
\hline Right male non-incumbents & $2.73(0.49)$ & $3.56(0.50)$ & 575 \\
p-value of difference & 0.035 & 0.001 & $3.31(0.55)$ \\
Left male non-incumbents & $2.57(0.57)$ & $3.39(0.50)$ & \\
\hline All parliamentary candidates & $2.78(0.66)$ & party & \\
\hline
\end{tabular}

Notes: Right candidates belong to the National Coalition Party. Left candidates belong to the Social Democratic Party or to the

Left Alliance. An incumbent is a political candidate who served in the office in question, or as a member of the European parliament, at the time of the election. One observation is the average evaluation of one candidate. P-values from a t-test of equal means are reported between each pair of average evaluations of right and left candidates.

\subsection{Electoral Success}

As shown in Table 4, the differences between right and left candidates that were evident in the municipal elections seem to be absent in the parliamentary election. There is a beauty premium for both left and right candidates such that a beauty increase of one standard deviation attracts about $20 \%$ more votes for the average non-incumbent candidate. Competence displays a weaker relationship with electoral success, which is statistically significant for left candidates in columns 4-6. However, this relationship is weakened substantially and becomes statistically insignificant both for left and right candidates when beauty is included in the regression (in columns 7-9). 
TABLE 4. Relative success in the parliamentary elections, non-incumbents.

\begin{tabular}{|c|c|c|c|c|c|c|c|c|c|}
\hline & $(1)$ & $(2)$ & (3) & (4) & $(5)$ & (6) & (7) & $(8)$ & (9) \\
\hline$\overline{\text { Beauty }}$ & $\begin{array}{l}24.47^{* * *} \\
(5.90)\end{array}$ & $\begin{array}{l}23.90 * * * \\
(5.86)\end{array}$ & $\begin{array}{c}21.82 * * * \\
(6.05)\end{array}$ & & & & $\begin{array}{c}20.82 * * * \\
(6.01)\end{array}$ & $\begin{array}{l}19.95^{* * * *} \\
(5.89)\end{array}$ & $\begin{array}{c}18.03 * * * \\
(6.19)\end{array}$ \\
\hline Beauty $\times$ Right & $\begin{array}{l}-2.26 \\
(9.75)\end{array}$ & $\begin{array}{l}-0.54 \\
(9.20)\end{array}$ & $\begin{array}{c}0.66 \\
(8.86)\end{array}$ & & & & $\begin{array}{c}-0.20 \\
(10.92)\end{array}$ & $\begin{array}{c}2.35 \\
(10.70)\end{array}$ & $\begin{array}{c}2.49 \\
(8.97)\end{array}$ \\
\hline Competence & & & & $\begin{array}{c}16.54 * * * \\
(5.11)\end{array}$ & $\begin{array}{c}16.85 * * * \\
(5.18)\end{array}$ & $\begin{array}{c}15.72 * * * \\
(4.89)\end{array}$ & $\begin{array}{c}9.11 \\
(4.83)\end{array}$ & $\begin{array}{l}9.70 * \\
(4.84)\end{array}$ & $\begin{array}{l}9.09 * \\
(4.66)\end{array}$ \\
\hline Competence $\times$ Right & & & & $\begin{array}{c}-7.50 \\
(10.49)\end{array}$ & $\begin{array}{l}-7.50 \\
(10.49)\end{array}$ & $\begin{array}{l}-3.51 \\
(9.55)\end{array}$ & $\begin{array}{c}-3.80 \\
(11.33)\end{array}$ & $\begin{array}{l}-5.83 \\
(11.43)\end{array}$ & $\begin{array}{l}-1.68 \\
(9.04)\end{array}$ \\
\hline Male dummy & $\begin{array}{l}13.50 \\
(6.99)\end{array}$ & $\begin{array}{l}11.89 \\
(8.10)\end{array}$ & $\begin{array}{c}9.93 \\
(9.18)\end{array}$ & $\begin{array}{c}4.36 \\
(7.39)\end{array}$ & $\begin{array}{l}3.40 \\
(8.77)\end{array}$ & $\begin{array}{c}0.81 \\
(9.60)\end{array}$ & $\begin{array}{l}11.67^{*} \\
(6.87)\end{array}$ & $\begin{array}{c}9.92 \\
(8.47)\end{array}$ & $\begin{array}{c}7.67 \\
(9.56)\end{array}$ \\
\hline Male dummy $\times$ Right & & $\begin{array}{c}5.33 \\
(15.75)\end{array}$ & $\begin{array}{c}10.01 \\
(17.26)\end{array}$ & & $\begin{array}{c}3.83 \\
(16.07)\end{array}$ & $\begin{array}{c}8.09 \\
(17.02)\end{array}$ & & $\begin{array}{c}6.12 \\
(14.50)\end{array}$ & $\begin{array}{c}9.62 \\
(16.79)\end{array}$ \\
\hline Age dummies & Yes & Yes & Yes & Yes & Yes & Yes & Yes & Yes & Yes \\
\hline $\begin{array}{l}\text { Education and } \\
\text { occupation dummies }\end{array}$ & No & No & Yes & No & No & Yes & No & No & Yes \\
\hline $\begin{array}{l}\text { Unreported dummies } \\
\text { interacted with Right }\end{array}$ & No & Yes & Yes & No & Yes & Yes & No & Yes & Yes \\
\hline List fixed effects & Yes & Yes & Yes & Yes & Yes & Yes & Yes & Yes & Yes \\
\hline Number of candidates & 485 & 485 & 485 & 485 & 485 & 485 & 485 & 485 & 485 \\
\hline R-squared & 0.06 & 0.06 & 0.18 & 0.02 & 0.01 & 0.15 & 0.06 & 0.06 & 0.18 \\
\hline
\end{tabular}

Notes: The dependent variable is Relative success. Right candidates belong to the National Coalition Party. Left candidates belong to the Social Democratic Party or to the Left Alliance. The education dummies are Comprehensive school or less (at most 10 years of schooling); Upper-secondary education (corresponds to 12 years of schooling); Vocational education (10-12 years of schooling); and University education (those who have completed their education and obtained degrees). Upper-secondary education usually serves as preparation for university-level education, and many of the candidates with upper-secondary education listed as highest education have started, but not completed, university studies. Vocational education includes, e.g., basic nurses, nurses, commercial school graduates, clerks, and artisans. The occupational dummies are political leader, party worker, management, researcher, teacher, upper white collar, medical doctor, nurse, lower white collar, worker, entrepreneur, artist, student, and not employed. Robust standard errors clustered at the list level in parentheses. * significant at $10 \%$; ** significant at $5 \% ; * *$ significant at $1 \%$.

Similarly, the estimated gender differences in the parliamentary election (Table 4) are quite small when compared with the municipal elections (Table 2). The male dummy is positive, but small and statistically insignificant, both for left and right candidates. Thus, candidate appearance and gender follow the same pattern of having noticeably larger differences between left and right candidates in the municipal elections. The reason, in our interpretation, is that voters have access to much more information about the candidates in parliamentary elections. Table A.6 presents results when incumbents are included. As with municipal elections, an incumbency dummy trumps other explanatory variables by an order of magnitude. 
Yet, both beauty and competence evaluations maintain their statistical significance.

\section{Interpretation}

We have established that right candidates look better than left candidates and that there is larger beauty premium for right candidates in municipal, but not in parliamentary, elections. We now turn to discussing possible interpretations of these findings.

Why do candidates on the right look better than candidates on the left? One potential explanation is that better-looking candidates sort into the party where beauty is more productive electorally. While our results are consistent with this explanation, our data are not suited for testing it. Hamermesh and Biddle (1994) report weak evidence that beautiful people sort into occupations where their looks are productive. This form of selection could be at hand even though jobs are not as easily substitutable on the political labor market and even if people choose parties purely in accordance with their ideological conviction. All it requires is that people who have found conservatism appealing or have joined a right party are more likely to run for office if they look good (since they figure that their appearance will help them).

A second possible explanation is a general relationship between looks and political opinions. A simple economic explanation could be that beautiful people earn more money on the labor market (Hamermesh and Biddle, 1994) and are therefore - for selfish reasons - more inclined to oppose redistribution and support parties to the right. A more general psychological explanation could be that good-looking people are more likely to perceive the world as a just place (since they are treated better than others) - and are therefore inclined to embrace conservative opinions. An empirical analysis by Price at al. (2011) supports a link between indicators of attractiveness and measures of attitudes towards egalitarianism (typically associated with the left). For example, they find that greater self-reported attractiveness is negatively related to a preference for egalitarianism.

Why might beauty premia differ across the political spectrum? Our preferred explanation is that voters use beauty as an informational cue when evaluating candidates. If right voters expect better-looking 
candidates to be closer to them ideologically, then the beauty premium should be higher on the right. On the basis of the Price et al. (2001) findings, one possibility is that beauty serves as an indication of nonegalitarianism, a political stance typically associated with sympathizers of the political right. It could also be that voters on the right, compared to voters on the left, consider beauty a stronger indication of candidate quality. Both of these explanations clarify why the partisan difference is present only at the municipal level. ${ }^{16}$ How so? At that level, voters have less certain information about candidates' true degree of non-egalitarianism or quality, which is why they rely on thin slices of information to assess candidates. Hence, voters do not know much about challengers but are easily able to observe how they look. Thus voters tend to give a large weight to facial appearance when comparing challengers in the municipal elections. In the parliamentary election an additional piece of information becomes available about most challengers: their behavior in municipal office. With this information available voters reduce the weight given to facial appearance. Given the information about the municipal performance of parliamentary candidates, superficial expectations about beautiful politicians should no longer be that effective in parliamentary elections, pushing the beauty premia of left and right candidates towards equalization. ${ }^{17}$ In contrast, if the explanation were based on expressive voting (e.g., right-wing voters identifying with or cheering for "the beautiful winners") there would be no reason for the difference in beauty premia to appear in municipal elections only.

Could religion provide another reason for beauty being a more relevant cue for right voters? Since attractive people are perceived as more religious (Crandall et al., 2007; Naumann et al., 2009), conservative voters who care about religiosity may be more inclined to vote for good-looking candidates.

\footnotetext{
${ }^{16}$ Note that McDermott's (1997) findings on the electoral effects of gender in low-information elections corresponds to the interpretation that voters use beauty as a cue for ideology (rather than for candidate quality).

${ }^{17}$ Furthermore, right candidates are better-looking than left candidates in municipal elections, as can be seen in Table 1 . As most candidates for parliamentary elections are picked among those who have experience from municipal politics, we should expect the right candidates to look better than the left candidates in parliamentary elections already for the reason that the set from which the former are selected has better looks.
} 
We are able to investigate this explanation by using voting data from a hypothetical election. The respondents in our study were asked to vote for one of four candidates (the ones they had just evaluated). ${ }^{18}$ Table 5 reports separately for religious and non-religious respondents the fraction of candidates who were selected in the hypothetical election who were also picked as the best looking one. The differences are minor and not statistically significant, whether looking at mixed-gender or same-gender hypothetical elections. Religious voters are, however, considerably more likely to vote for a male candidate.

TABLE 5. Religious voting in a hypothetical election.

\begin{tabular}{llll}
\hline & $\begin{array}{l}\text { Share of hypothetically } \\
\text { elected candidates who were } \\
\text { selected as best looking }\end{array}$ & $\begin{array}{l}\text { Share of hypothetically } \\
\text { elected candidates who were } \\
\text { men }\end{array}$ & $\begin{array}{l}\text { Share of elected candidates } \\
\text { who were selected as best } \\
\text { looking in same-gender } \\
\text { hypothetical elections }\end{array}$ \\
\hline Religious voters & $44.2 \%$ & $48.8 \%$ & $49.0 \%$ \\
Non-religious voters & $44.9 \%$ & $40.9 \%$ & $47.7 \%$ \\
\hline
\end{tabular}

Note: Religious voters stated that they "would only vote for a politician who believes in God" or that they "would rather vote for a politician who believes in God".

Finally, we cannot rule out the possibility that voters of candidates on the right differ on a neurocognitive level from voters of candidates on the left. There are several studies that point to neurocognitive foundations of political orientations and that connect them to basic psychological dispositions. ${ }^{19}$ Jost et al. (2003) perform a meta-analysis and find that psychological variables, such as death anxiety, intolerance of ambiguity, lack of openness to experiencing new things, need for order and fear of threat, predict a conservative political orientation. More recent studies showing relationships between personality or physiology and political orientation include Block and Block (2006), Westen et al. (2006), Amodio et al. (2007), Oxley et al. (2008), Chiao et al. (2009), Schreiber et al. (2009), Zamboni et

\footnotetext{
${ }^{18}$ The instruction read: "Sometimes people have to vote in an election with only a little information. Let us assume that you would have to either vote for one of these persons as a member of Parliament [non-US respondents]/the House of Representatives [US respondents], or abstain from voting. Which would be your choice?". (The response alternatives also included "Prefer not to answer".)

${ }^{19}$ The general approach of this research field is outlined in Fowler and Shreiber (2008).
} 
al. (2009) and Vigil (2010). ${ }^{20}$ While this literature does not clarify any mechanism for a link from neurocognitive or psychological differences between left and right sympathizers to different weights awarded to different aspects of physical appearance, such as beauty, it does suggest the possibility of such a mechanism.

\section{Concluding Discussion}

Our results indicate that political candidates from the right look better than political candidates from the left and that good looks are more important for candidates on the right in the municipal, but not in the parliamentary, elections. Our interpretation of this gap in the beauty premium for left and right candidates at the local level is that voters, in a setting with low information, use beauty as a cue for candidate ideology or quality. For instance, beautiful candidates seem less egalitarian. In the parliamentary elections, voters have access to more information, not least since most parliamentary candidates have been politicians at the municipal level, which reduces the weight of beauty as a cue and pushes the beauty premia of left and right candidates toward equalization.

Our findings contribute to a better understanding of the way politics de facto works. Not least, they point at a possible link from the way candidates look to policy outcomes: if voters reward beauty, the candidates with the best looks and their parties are at an advantage, and their political programs are more likely to be implemented. Differential beauty premia could give one side in politics an electoral advantage and the importance of such an advantage could depend on political institutions. As Lawson et al. (2010) point out, the role of appearance differs between electoral systems: some give more leeway for individual candidates rather than parties. This may in turn affect how important looks become in elections and, with differential electoral effects of beauty, whether one side of the political spectrum is favored relative to the

\footnotetext{
${ }^{20}$ Alford et al. (2005) show that the underlying basis of political attitudes and ideology may be genetic; cf. Fowler et al. (2008), Hatemi et al. (2009) and Settle et al. (2009).
} 
other. A broad interpretation of our findings is that the increased importance of television over the last decades, may have increased the electoral chances of the political right. In fact, Lenz and Lawson (2011) demonstrate that television leads less informed citizens to vote based on candidates' appearance.

Another possible consequence of our findings for low-information elections is that both left and right politicians will be more eager to please voters who are less willing to trade off policy against the benefits of good-looking politicians. This is in line with models in which parties target redistribution toward groups that are most responsive - see, e.g., Lindbeck and Weibull (1987) and Dixit and Londregan (1996). By the same reasoning, voters who care about the looks of candidates will find it more difficult to keep political rents at bay. Thus our findings also suggest that policy platforms could be geared towards the preferences of left voters and that right politicians might be able to capture bigger rents when in office.

The two consequences just described indicate that the differences in beauty premia could have an ambiguous effect on policy outcomes. On the one hand, beauty favors right candidates, in terms of getting elected, but on the other hand, political platforms will be geared to left voters to the extent that they care less about the looks of politicians.

Finally, our findings can be related to the different use of emotional tactics by political parties. For example, Westen (2007) suggests that whereas Republican strategists have understood that emotions decide election outcomes, Democrat strategists have clung to a dispassionate view of the mind, making them focus on rational argumentation, to their detriment. If we connect this point to our results, it could be that the Finnish National Coalition Party, whether consciously or unconsciously, has made use of candidates with a stronger emotional appeal. Clearly, there is scope for more research in this area. Pinpointing how the appearance of candidates on the left and on the right of the political spectrum influences the democratic process should be seen as an ongoing research program. 


\section{Appendix}

TABLE A.1. Factors that influenced voters in choosing parliamentary candidates.

\begin{tabular}{|c|c|c|}
\hline Influence & $\begin{array}{l}\text { Share of right voters being } \\
\text { significantly or somewhat } \\
\text { influenced }\end{array}$ & $\begin{array}{l}\text { Share of left voters being } \\
\text { significantly or somewhat } \\
\text { influenced }\end{array}$ \\
\hline Candidate's gender & $32 \%$ & $38 \%$ \\
\hline Candidate's age & $28 \%$ & $31 \%$ \\
\hline Candidate's educational background & $56 \%$ & $31 \%$ \\
\hline Candidate's previous experience in politics & $62 \%$ & $63 \%$ \\
\hline Candidate's presence and style & $39 \%$ & $34 \%$ \\
\hline Candidate's fame & $37 \%$ & $33 \%$ \\
\hline Candidate's views and comments & $87 \%$ & $80 \%$ \\
\hline $\begin{array}{l}\text { Candidate represents the party supported } \\
\text { by the voter }\end{array}$ & $85 \%$ & $73 \%$ \\
\hline $\begin{array}{l}\text { Candidate's election } \\
\text { campaign and advertisements }\end{array}$ & $25 \%$ & $21 \%$ \\
\hline $\begin{array}{l}\text { Recommendations } \\
\text { of a friend, aquintance or relative }\end{array}$ & $10 \%$ & $9 \%$ \\
\hline $\begin{array}{l}\text { Comments and support of a non- } \\
\text { governmental organization }\end{array}$ & $16 \%$ & $5 \%$ \\
\hline
\end{tabular}

Notes: Right candidates belong to the National Coalition Party. Left candidates belong to the Social Democratic Party or to the

Left Alliance. The numbers presented in the Table and in the paper refer to voters for these three parties.

Source: Karvonen and Paloheimo (2003). 
TABLE A.2. Occupational data for municipal and parliamentary candidates, $\%$.

\begin{tabular}{lcc}
\hline Occupation & $\begin{array}{c}\text { Municipal } \\
\text { Election }\end{array}$ & $\begin{array}{c}\text { Parliamentary } \\
\text { Election }\end{array}$ \\
\hline Political leader & 2.4 & 12.9 \\
Party worker & 2.3 & 2.2 \\
Management & 6.3 & 5.5 \\
Researcher & 3.9 & 3.6 \\
Teacher & 7.2 & 10.0 \\
Upper white collar & 10.7 & 9.8 \\
Medical doctor & 1.3 & 3.4 \\
Nurse & 4.7 & 5.0 \\
Lower white collar & 12.3 & 11.0 \\
Worker & 16.8 & 14.1 \\
Entrepreneur & 6.0 & 5.1 \\
Artist & 2.2 & 2.0 \\
Student & 8.8 & 5.4 \\
Not employed & 2.8 & 1.5 \\
Not listed & 12.2 & 8.5 \\
\hline
\end{tabular}

Not listed $12.2 \quad 8.5$

Notes: The occupation data is reported on electoral lists and have been classified by us according to the classification of

Statistics Finland (2001), though we have merged certain occupational categories with a small number of candidates and listed party workers as a group of their own. 
TABLE A.3. Average trait evaluations according to respondent ideology (standard deviations in parentheses).

\begin{tabular}{lllll}
\hline Candidates & Respondents & Beauty & Competence & Number of candidates \\
\hline Right & Right & $2.96(0.70)$ & $3.40(0.54)$ & 244 \\
$\quad$ p-value of difference & & 0.0000 & 0.0012 & \\
Left & Right & $2.65(0.72)$ & $3.25(0.60)$ & 459 \\
\hline Right & Left & $2.85(0.75)$ & $3.45(0.53)$ & 169 \\
$\quad$ p-value of difference & & 0.0014 & 0.0043 & \\
Left & Left & $2.62(0.73)$ & $3.29(0.63)$ & 343 \\
\hline Right female & Right & $3.07(0.80)$ & $3.33(0.49)$ & 133 \\
$\quad$ p-value of difference & & 0.0000 & 0.0532 & \\
Left female & Right & $2.70(0.80)$ & $3.21(0.58)$ & 233 \\
\hline Right female & Left & $3.08(0.83)$ & $3.42(0.52)$ & 89 \\
$\quad$ p-value of difference & & 0.0067 & 0.0805 & \\
Left female & Left & $2.77(0.78)$ & $3.29(0.58)$ & 159 \\
\hline Right male & Right & $2.84(0.55)$ & $3.49(0.59)$ & 111 \\
$\quad$ p-value of difference & & 0.0007 & 0.0055 & \\
Left male & Right & $2.60(0.63)$ & $3.29(0.61)$ & 226 \\
\hline Right male & Left & $2.59(0.55)$ & $3.49(0.54)$ & 80 \\
$\quad$ p-value of difference & & 0.3093 & 0.0212 & \\
Left male & Left & $2.50(0.66)$ & $3.29(0.68)$ & 184 \\
\hline$\quad$ Notes: The Table
\end{tabular}

Notes: The Table contains candidates both from the municipal and the parliamentary elections. Right candidates belong to the

National Coalition Party. Left candidates belong to the Social Democratic Party or to the Left Alliance. One observation is the average evaluation of one candidate. Right respondents "strongly disagree" or "somewhat disagree" with the suggestion "to increase taxes on those with high incomes in your country, and distribute the money to those with low incomes". Left respondents "strongly agree" or "somewhat agree" with the same suggestion. P-values from a t-test of equal means are reported between each pair of average evaluations for right and left candidates. 
TABLE A.4. Average trait evaluations according to respondent country (standard deviations in parentheses).

\begin{tabular}{|c|c|c|c|c|}
\hline Candidates & $\begin{array}{l}\text { Respondents' } \\
\text { country }\end{array}$ & Beauty & Competence & $\begin{array}{l}\text { Number of } \\
\text { candidates }\end{array}$ \\
\hline Right & Sweden & $2.85(0.75)$ & $3.45(0.53)$ & 137 \\
\hline p-value of difference & & 0.0003 & 0.0094 & \\
\hline Left & Sweden & $2.56(0.76)$ & $3.27(0.68)$ & 261 \\
\hline Right & United States & $2.94(0.78)$ & $3.40(0.56)$ & 170 \\
\hline p-value of difference & & 0.0000 & 0.0095 & \\
\hline Left & United States & $2.62(0.78)$ & $3.25(0.65)$ & 328 \\
\hline Right female & Sweden & $3.14(0.77)$ & $3.54(0.51)$ & 68 \\
\hline p-value of difference & & 0.0000 & 0.0007 & \\
\hline Left female & Sweden & $2.65(0.79)$ & $3.23(0.64)$ & 124 \\
\hline Right female & United States & $3.03(0.87)$ & $3.35(0.50)$ & 98 \\
\hline $\mathrm{p}$-value of difference & & 0.0006 & 0.0697 & \\
\hline Left female & United States & $2.65(0.85)$ & $3.23(0.55)$ & 165 \\
\hline Right male & Sweden & $2.56(0.61)$ & $3.35(0.54)$ & 69 \\
\hline p-value of difference & & 0.4033 & 0.6503 & \\
\hline Left male & Sweden & $2.48(0.73)$ & $3.31(0.71)$ & 137 \\
\hline Right male & United States & $2.82(0.62)$ & $3.46(0.63)$ & 72 \\
\hline $\mathrm{p}$-value of difference & & 0.0168 & 0.0476 & \\
\hline Left male & United States & $2.59(0.69)$ & $3.27(0.73)$ & 163 \\
\hline
\end{tabular}

Notes: The Table contains candidates both from the municipal and the parliamentary elections. Right candidates belong to the

National Coalition Party. Left candidates belong to the Social Democratic Party or to the Left Alliance. One observation is the average evaluation of one candidate. P-values from a t-test of equal means are reported between each pair of average evaluations for right and left candidates. 
TABLE A.5. Average trait evaluations according to candidate attire (standard deviations in parentheses).

\begin{tabular}{|c|c|c|c|c|c|}
\hline Respondents & Candidates & $\begin{array}{l}\text { Tie or blouse } \\
\text { and/or suite }\end{array}$ & Beauty & Competence & $\begin{array}{l}\text { Number of } \\
\text { candidates }\end{array}$ \\
\hline All & All & Yes & $2.75(0.67)$ & $3.41(0.46)$ & 823 \\
\hline \multicolumn{2}{|c|}{ p-value of difference } & & 0.1751 & 0.0000 & \\
\hline All & All & No & $2.70(0.64)$ & $3.16(0.45)$ & 534 \\
\hline Right & All & Yes & $2.77(0.75)$ & $3.42(0.59)$ & 424 \\
\hline \multicolumn{2}{|c|}{ p-value of difference } & & 0.4661 & 0.0000 & \\
\hline Right & All & No & $2.73(0.70)$ & $3.13(0.52)$ & 279 \\
\hline Left & All & Yes & $2.70(0.74)$ & $3.44(0.60)$ & 316 \\
\hline \multicolumn{2}{|c|}{ p-value of difference } & & 0.9118 & 0.0000 & \\
\hline Left & All & No & $2.69(0.75)$ & $3.18(0.57)$ & 196 \\
\hline Right & Female & Yes & $2.83(0.85)$ & $3.35(0.57)$ & 225 \\
\hline \multicolumn{2}{|c|}{ p-value of difference } & & 0.9937 & 0.0001 & \\
\hline Right & Female & No & $2.83(0.76)$ & $3.11(0.50)$ & 141 \\
\hline Right & Male & Yes & $2.71(0.61)$ & $3.50(0.61)$ & 199 \\
\hline \multicolumn{2}{|c|}{ p-value of difference } & & 0.2565 & 0.0000 & \\
\hline Right & Male & No & $2.63(0.62)$ & $3.15(0.54)$ & 138 \\
\hline Left & Female & Yes & $2.84(0.79)$ & $3.36(0.60)$ & 169 \\
\hline \multicolumn{2}{|c|}{$\mathrm{p}$-value of difference } & & 0.3409 & 0.2848 & \\
\hline Left & Female & No & $2.95(0.84)$ & $3.28(0.45)$ & 79 \\
\hline Left & Male & Yes & $2.54(0.64)$ & $3.54(0.59)$ & 147 \\
\hline \multicolumn{2}{|c|}{ p-value of difference } & & 0.8420 & 0.0000 & \\
\hline Left & Male & No & $2.52(0.62)$ & $3.12(0.64)$ & 117 \\
\hline
\end{tabular}

Notes: The Table contains candidates both from the municipal and the parliamentary elections. Right candidates belong to the National Coalition Party. Left candidates belong to the Social Democratic Party or to the Left Alliance. One observation is the average evaluation of one candidate. P-values from a t-test of equal means are reported between each pair of average evaluations for candidates who wear a tie (for men) or blouse and/or suite (for women) and candidates who do not. 
TABLE A.6. Relative success in the municipal and parliamentary elections, incumbents and non-incumbents.

\begin{tabular}{lcccc}
\hline & $\begin{array}{c}(1) \\
\text { Municipal }\end{array}$ & $\begin{array}{c}(2) \\
\text { Municipal } \\
\text { Election }\end{array}$ & $\begin{array}{c}\text { Parliamentary } \\
\text { election }\end{array}$ & $\begin{array}{c}\text { Parliamentary } \\
\text { election }\end{array}$ \\
\hline Beauty & $17.07^{* *}$ & 7.49 & $16.95^{* * *}$ & $15.68^{* *}$ \\
& $(6.55)$ & $(6.82)$ & $(5.67)$ & $(5.98)$ \\
Beauty $\times$ Right & 3.03 & 5.31 & -8.32 & -8.98 \\
& $(6.59)$ & $(7.19)$ & $(9.78)$ & $(7.91)$ \\
Competence & -2.03 & 1.97 & $11.48^{* * *}$ & $12.55^{* *}$ \\
& $(10.64)$ & $(7.37)$ & $(3.38)$ & $(4.12)$ \\
Competence $\times$ Right & -0.64 & -10.18 & -14.30 & $-14.03^{*}$ \\
& $(11.93)$ & $(8.51)$ & $(9.46)$ & $(7.78)$ \\
Incumbent & $466.59^{* * *}$ & $309.95^{* * *}$ & $224.63^{* * *}$ & $72.60^{* * *}$ \\
& $(100.75)$ & $(89.99)$ & $(38.69)$ & $(23.13)$ \\
Incumbent $\times$ Right & $-207.24^{*}$ & -119.37 & -69.27 & $-62.77^{* *}$ \\
& $(111.18)$ & $(99.91)$ & $(51.01)$ & $(25.65)$ \\
Male dummy & $-25.35^{*}$ & $-29.82^{* *}$ & -7.83 & -7.85 \\
& $(13.20)$ & $(9.00)$ & $(9.66)$ & $(12.05)$ \\
Male dummy $\times$ Right & $27.79^{*}$ & $21.95^{* *}$ & $24.90^{*}$ & $31.85^{*}$ \\
& $(13.44)$ & $(9.20)$ & $(13.30)$ & $(16.95)$ \\
Age dummies & Yes & Yes & Yes & Yes \\
Education and occupation dummies & No & Yes & No & Yes \\
Unreported variables interacted with Right & Yes & Yes & Yes & Yes \\
List fixed effects & Yes & Yes & Yes & Yes \\
Number of candidates & 779 & 779 & 575 & 575 \\
R-squared & 0.41 & 0.59 & 0.23 & 0.28 \\
\hline N & & &
\end{tabular}

Notes: The dependent variable is Relative success. Right candidates belong to the National Coalition Party. Left candidates belong to the Social Democratic Party or to the Left Alliance. Robust standard errors clustered at the list level in parentheses. The estimated models include list fixed effects. * significant at $10 \%$;* significant at $5 \%$; ** significant at $1 \%$. 


\section{References}

Alford, John R., Carolyn L. Funk, and John R. Hibbing (2005). “Are Political Orientations Genetically Transmitted?” American Political Science Review, 99(2), 153-167.

Amodio, David M., John T. Jost, Sarah L. Master, and Cindy M. Yee (2007). "Neurocognitive Correlates of Liberalism and Conservatism.” Nature Neuroscience, 10(10), 1246-1247.

Andreoni, James, and Ragan Petrie (2008). "Beauty, Gender and Stereotypes: Evidence from Laboratory Experiments.” Journal of Economic Psychology, 29(1), 73-93.

Antonakis, John, and Olaf Dalgas (2009). "Predicting Elections: Child's Play!” Science, 323(5918), 1183.

Ballew II, Charles C., and Alexander Todorov (2007). "Predicting Political Elections from Rapid and Unreflective Face Judgments." Proceedings of the National Academy of Sciences of the United States of America, 104(46), 17948-17953.

Benjamin, Daniel J., and Jesse M. Shapiro (2009). "Thin-Slice Forecasts of Gubernatorial Elections.” Review of Economics and Statistics, 91(3), 523-536.

Berggren, Niclas, Henrik Jordahl, and Panu Poutvaara (2010). “The Looks of a Winner: Beauty and Electoral Success.” Journal of Public Economics, 94(1-2), 8-15.

Block, Jack, and Jeanne H. Block (2006). "Nursery School Personality and Political Orientation Two Decades Later.” Journal of Research in Personality, 40(5), 734-749.

Bobbio, Norberto (1996). Left \& Right: The Significance of a Political Distinction. Cambridge: Polity Press.

Buckley, Fiona, Neil Collins, and Theresa Reidy (2007). "Ballot Paper Photographs and Low-Information Elections in Ireland." Politics, 27(3), 174-181.

Budge, Ian, and David Robertson (1987). "Do Parties Differ, and How? Comparative Discriminant and Factor Analysis.” In Ideology, Strategy and Party Change: Spatial Analyses of Post-War Election Programmes in Nineteen Democracies, edited by Ian Budge, Derek Hearl and David Robertson. Cambridge: Cambridge University Press.

Caughey, Devin. M., and Jasjeet S. Sekhon (2010). "Regression-Discontinuity Designs and Popular Elections: Implications of Pro-Incumbent Bias in Close US House Races.” Travers Department of Political Science, UC Berkeley.

Chiao, Joan Y., Vani A. Mathur, Tokiko Harada, and Trixie Lipke (2009). "Neural Basis of Preference for Human Social Hierarchy Versus Egalitarianism.” Annals of the New York Academy of Sciences, 1167(1), 174-181.

Crandall, Tiffany L., Garett P. DaBell, Jessica L. DaBell, Karen S. Findley, Matthew D. Kammeyer, and Meghan Nielsen (2007). “The Halo Effect and Religiosity: Are Attractive People Perceived as More Religious?” BYU Undergraduate Journal of Psychology, 3, 19-22.

Darwin, Charles (1871). The Descent of Man and Selection in Relation to Sex. London: John Murray. 
Dixit, Avinash, and John Londregan (1996). "The Determinants of Success of Special Interests in Redistributive Politics." Journal of Politics, 58(4), 1132-1155.

Dreber, Anna, Christer Gerdes, and Patrik Gränsmark (2010). "Beauty Queens and Battling Knights: Risk Taking and Attractiveness in Chess.” IZA Discussion Paper No. 5314. Institute for the Study of Labor.

Fowler, James H., Laura A. Baker, and Christopher T. Dawes (2008). "Genetic Variation in Political Participation." American Political Science Review, 102(2), 233-248.

Fowler, James H., and Darren Schreiber (2008). "Biology, Politics, and the Emerging Science of Human Nature." Science, 322(5903), 912-914.

Grammer, Karl, Bernhard Fink, Anders P. Møller, and Randy Thornhill (2003). "Darwinian Aesthetics Sexual Selection and the Biology of Beauty.” Biological Reviews, 78(3), 385-407.

Grendstad, Gunnar (2003). “Reconsidering Nordic Party Space.” Scandinavian Political Studies, 26(3), 193-217.

Hamermesh, Daniel S., and Jeff E. Biddle (1994). "Beauty and the Labor Market.” American Economic Review, 84(5), 1174-1194.

Hamermesh, Daniel S., Xin Meng, and Junsen Zhang (2002). “Dress for Success - Does Primping Pay?” Labour Economics, 9(3), 361-373.

Hatemi, Peter K., John R. Alford, John R. Hibbing, Nicholas G. Martin, and Lindon J. Eaves (2009). Is There a 'Party' in Your Genes?” Political Research Quarterly, 62(3), 584-600.

Jost, John T., Jack Glaser, Arie W. Kruglanski, and Frank J. Sulloway (2003). "Political Conservatism as Motivated Social Cognition.” Psychological Bulletin, 129(3), 339-375.

Kanazawa, Satoshi (2011). "Intelligence and Physical Attractiveness.” Intelligence, 39(1), 7-14.

Karvonen, Lauri, and Heikki Paloheimo (2003). Finnish National Election Study 2003. Computer file FSD1260, version 1.0 (2003-10-09). Data collected in 2003 by TNS Gallup Finland, Espoo. Producer: Elections and Representative Democracy in Finland research group. Distributor: Finnish Social Science Data Archive, Tampere.

King, Amy, and Andrew Leigh (2009). "Beautiful Politicians.” Kyklos, 62(4), 579-593.

Klingemann, Hans-Dieter. (1995). "Party Positions and Voter Orientations.” In Citizens and the State, edited by Hans-Dieter Klingemann and Dieter Fuchs. Oxford: Oxford University Press.

Langlois, Judith H., Lisa Kalakanis, Adam J. Rubenstein, Andrea Larson, Monica Hallamm, and Monica Smoot (2000). "Maxims or Myths of Beauty? A Meta-Analytic and Theoretical Review." Psychological Bulletin, 126(3), 390-423.

Lawson, Chappell, Gabriel S. Lenz, Andy Baker, and Michael Myers (2010). "Looking Like a Winner: Candidate Appearance and Electoral Success in New Democracies.” World Politics, 62(4), 561-593.

Lenz, Gabriel S., and Chappell Lawson (2011). "Looking the Part: Television Leads Less Informed Citizens to Vote Based on 
Candidates’ Appearance.” American Journal of Political Science, forthcoming.

Lindbeck, Assar, and Jörgen Weibull (1987). "Balanced-Budget Redistribution as the Outcome of Political Competition.” Public Choice, 52(3), 272-297.

Mair, Peter (2007). “Left-Right Orientations.” In The Oxford Handbook of Political Behavior, edited by Russel J. Dalton and Hans-Dieter Klingemann. Oxford: Oxford University Press.

McDermott, Monica L. (1997). "Voting Cues in Low-Information Elections.” American Journal of Political Science, 41(1), 270283.

Mobius, Markus M., and Tanya S. Rosenblat (2006). “Why Beauty Matters.” American Economic Review, 96(1), 222-235.

Mulford, Matthew, John Orbell, Cathrine Shatto, and Jean Stockard (1998). "Physical Attractiveness, Opportunity and Success in Everyday Exchange.” American Journal of Sociology, 103(6), 1565-1593.

Naumann Laura P., Simine Vazire, Peter J. Rentfrow, and Samuel D. Gosling (2009). "Personality Judgments Based on Physical Appearance.” Personality and Social Psychology Bulletin, 35(12), 1661-1671.

Nurmi, Hannu, and Lasse Nurmi (2004). "The Parliamentary Election in Finland, March 2003.” Electoral Studies, 23(3), 557565.

Olivola, Christopher Y., and Alexander Todorov (2010). "Elected in 100 Milliseconds: Appearance-Based Trait Inferences and Voting." Journal of Nonverbal Behavior, 34(2), 83-110.

Oxley, Douglas R., Kevin B. Smith, John R. Alford, Matthew V. Hibbing, Jennifer L. Miller, Mario Scalora, Peter K. Hatemi, and John R. Hibbing (2008). “Politicial Attitudes Vary with Physiological Traits.” Science, 321(5896), 1667-1670.

Price, Michael E., Jinsheng Kang, James Dunn, and Sian Hopkins (2011). "Muscularity and Attractiveness as Predictors of Human Egalitarianism.” Personality and Individual Differences, forthcoming.

Poutvaara, Panu, Henrik Jordahl, and Niclas Berggren (2009). "Faces of Politicians: Babyfacedness Predicts Inferred Competence but Not Electoral Success.” Journal of Experimental Social Psychology, 45(5), 1132-1135.

Raunio, Tapio (2005). “Finland: One Hundred Years of Quietude.” In The Politics of Electoral Systems, edited by Michael Gallagher and Paul Mitchell. Oxford: Oxford University Press.

Rule, Nicholas O., and Nalini Ambady (2008). “The Face of Success: Inferences from Chief Executive Officers' Appearance Predict Company Profits.” Psychological Science, 19(2), 109-111.

Rule, Nicholas O., Nalini Ambady, Reginald B. Adams Jr., Hiroki Ozono, Sakiko Nakashima, Satoshi Yoshikawa, and Motoki Watabe (2010). "Polling the Face: Prediction and Consensus Across Cultures." Journal of Personality and Social Psychology, 98(1), 1-15.

Schreiber, Darren, Allan N. Simmons, Christopher T. Dawes, Taru Flagan, James H. Fowler, and Martin P. Paulus (2009). "Red Brain, Blue Brain: Evaluative Processes Differ in Democrats and Republicans.” Working Paper, Department of Political 
Science, University of California San Diego.

Settle, James E., Christopher T. Dawes, and James H. Fowler (2009). “The Heritability of Partisan Attachment.” Political Research Quarterly, 62(3), 601-613.

Solnick, Sara J., and Maurice E. Schweitzer (1999). “The Influence of Physical Attractiveness and Gender on Ultimatum Game Decisions." Organizational Behavior and Human Decision Processes, 79(3), 199-215.

Statistics Finland (2001). Classification of Occupations 2001. Available at http://tilastokeskus.fi/tk/tt/luokitukset/lk_en/ammatti_index.html.

Todorov, Alexander, Anesu N. Mandisodza, Amir Goren, and Crystal C. Hall (2005). "Inferences of Competence from Faces Predict Election Outcomes.” Science, 308(5728), 1623-1626.

Todorov, Alexander, Christopher P. Said, and Sara C. Verosky (2011). "Personality Impressions from Facial Appearance". In Oxford Handbook of Face Perception, edited by Andy Calder, Gillian Rhodes, Mark Johnson and Jim Haxby. Oxford: Oxford University Press, forthcoming.

Vigil, Jacob M. (2010). "Political Leanings Vary with Facial Expression Processing and Psychosocial Functioning." Group Processes Intergroup Relations, 13(5), 547-588.

Westen, Drew (2007). The Political Brain: The Role of Emotion in Deciding the Fate of the Nation. New York: Public Affairs.

Westen, Drew, Pavel S. Blagov, Keith Harenski, Clint Kilts, and Stephan Hamann (2006). "Neural Bases of Motivated Reasoning: An fMRI Study of Emotional Constraints on Partisan Political Judgment in the 2004 U.S. Presidential Election." Journal of Cognitive Neuroscience, 18(11), 1947-1958.

Wilson, Rick K., and Cathrine C. Eckel (2006). "Judging a Book by its Cover: Beauty and Expectations in the Trust Game." Political Research Quarterly, 59(2), 189-202.

Zamboni, Giovanna, Marta Gozzi, Frank Krueger, Jean-René Duchamel, Angela Sirigu, and Jordan Grafman (2009). "Individualism, Conservatism, and Radicalism as Criteria for Processing Political Beliefs: A Parametric fMRI Study." Social Neuroscience, 4(5), 367-383.

Zechmeister, Elizabeth (2006). “What's Left and Who's Right? A Q-Method Study of Individual and Contextual Influences on the Meaning of Ideological Labels.” Political Behavior, 28(2), 151-173. 